\title{
Kāmākhya, den menstruerende gudinde - tantrisme for lægfolk og elite
}

\author{
MARIANNE QVORTRUP FIBIGER
}

ENGLISH ABSTRACT: Based on an analysis of the cult around the tantric goddess Kāmākhya from Assam, I will discuss her appeal for both laypeople and ascetics. A special feature is that she menstruates and that her blood is given thaumaturgical as well as transformative properties. For laypeople the hope is that it will have a positive effect on their lives here and now, and for the ascetics that it will give rise to an internal process with a soteriolgical goal in mind. In this relation, I shall present a differentiation between a hardcore and a softcore tantrism and furthermore their interrelationship.

DANSK RESUMÉ: Med udgangspunkt i en analyse af kulten omkring den tantriske gudinde Kāmakhya fra Assam diskuteres hendes brede appeal for både lægfolk og asketer. Det specielle ved gudinden er, at hun menstruerer, og at blodet tillægges både thaumaturgiske og transformative egenskaber. For lægfolk er håbet, at det kan have positiv effekt for deres liv nu og her, for asketer at det vil sætte gang $i$ en individuel proces med et soteriologisk mål for øje. I den forbindelse vil en skelnen imellem en hard core- og en soft core-tantrisme og deres interrelation blive præsenteret.

KEYWORDS: Kāmākhya tantrism; śaktism; thamaturgical and tranformative properties

I Nilachal højlandet i delstaten Assam i det nordøstlige Indien ${ }^{1}$ ligger templet for den menstruerende tantriske gudinde Kāmākhya ('Den berømte gudinde for begær'). Hvert år i juni måned valfarter såvel asketiske sādhugrupper som lægfolk til templet, når gudinden Kāmāakhya menstruerer. Menstruationsblodet, som almindeligvis forstås som urent, da det viser at et potentielt liv er blevet udstødt, anses i tilknytning til Kāmākhya-gudinden til at have såvel transformative som thaumaturgiske egenskaber - vel at mærke, hvis hun og blodet behandles efter de rituelle forskrifter, som er knyttet til kulten omkring hende. Her spiller præsterne ( $p \bar{u} j \bar{a} r i s)$ en betydelig

$1 \quad$ Nærmere bestemt i udkanten af byen Guwahati. 
rolle, idet det er dem, der i de tre-fire dage,,$^{2}$ hvor gudinden menstruerer, og hvor templet er lukket for alle andre, skal sikre, at hendes blod kanaliseres ud i den lokale flod Brahmaputra. Når flodens vand bliver rødt, er det et tegn på, at det urene eller måske mere præcist det destruktive er væk.

Denne balance og ikke mindst transformative ${ }^{3}$ bevægelse fra destruktiv urenhed til konstruktiv (u)renhed, og som kræver en overholdelse af en bestemt ortopraksi, er helt grundlæggende for at forstå, hvorfor denne gudinde har så stor og bred popularitet. For det første kan transformationen og transformationsprocessen tolkes bredt; for det andet kan det, hun repræsenterer og bevirker, indskrives i forskellige ontologier. ${ }^{4}$ Dyrkningen af Kāmākhya generelt og det 'faktum', at hun menstruerer, kan derfor både passe ind i en lægmands-kollektivt orienteret pragmatisme med håbet om at få udfyldt dennesidige behov, og i en esoterisk, individuelt fokuseret soteriologi eller soteri-ontologi (se note 4). Det kan i en bellahsk kulturevolutionistisk typologi henholdsvis betegnes som en arkaisk religionsform med en mytologisk begrundet teologi og i en aksial religionsform med fokus på askese og individets frigørelse af livet som lidelsesfuld (duhkha) (Bellah 2011). Vi bør dog i sammenhæng med Kāmākhya-kulten nok snarere kategorisere den asketiske religionsform som post-aksial, idet den på mange måder er institutionaliseret.

\section{Kāmākhya-kulten, tantrisme og menstruationsblodets betydning}

Kāmākhya-gudinden er tantrisk. Tantrisme er som udgangspunkt en esoterisk asketisk bevægelse eller måske snarere strømning, som opstod i det nordlige Indien omkring 500-tallet evt., hvor den både blev indlejret i hinduistiske, jainistiske og buddhistiske systemer. I buddhismen har den haft stor betydning for udviklingen af vajrayāna-buddhismen, også kaldet den nordlige buddhisme, som især kommer til udtryk i tibetansk buddhisme. I hinduismen er tantrisme især kendt som basis for forskellige sādhu-grupper, som er opstået op igennem den indiske middelalder og som på forskellig vis benytter sig af tantriske teknikker for at transformere kroppen. Formålet med tantrismen er overordnet set at overvinde enhver dualitet også mellem

2 Visse kilder skriver tre, andre fire, dage, se henholdsvis Urban (2008) og Biernacki (2007) samt forskellige populære hjemmesider om templet som fx https://www.reckontalk.com/secrets-ofkamakhya-devi-temple-menstruating-goddess-in-india/

3 Netop transformationen af det urene fra en destruktiv til en konstruktiv kraft er også det, Mikael Aktor understreger i sin artikel "'Respect Pollution' - urenhed og renselse i hinduismens rituelle personhierarki" i dette nummer 69 af Religionsvidenskabeligt Tidsskrift. Aktor henviser til Mary Douglas sidste kapitel af hendes bog Purity and Danger (Douglas 1984, 159-179), hvor hun understreger, at der i selve forbuddet og eksklusionen ligger en rituel energi, der kan transformeres og benyttes positiv. Dette ligger også tæt op ad David White forståelse af tantrisme, som han netop ser som transformation af energi.

4 Her tænker jeg ikke mindst på de af Descola (2013) foreslåede ontologier: den tribale, den animistiske, den analogistiske og den naturalistiske, men udvidet med den af Knut Jacobsens (2007b) foreslåede soteriologiske. Han kalder den en soterio-ontologi. Det dækker over en ontologi hvor verdens beskaffenhed og indretning indskrives i en soteriologisk bestræbelse. Igennem en erkendelse af at verden er $d u h k h a$ (lidelse, ikke tilfredsstillende), kan man frigøre sig fra den. 
det mandlige og det kvindelige, som både er at finde i den yderste virkelighed og i kroppen selv. Frigørelsen fra denne verden opnås igennem ritualer, hvor de to poler forenes. Disse teknikker, der har det transformative som fokuspunkt, bliver sammen med denne overordnede ontologi og i visse sammenhænge også i teologier, beskrevet i den tekstgruppe, som samles kaldes tantraer. Selvom tantraerne er esoteriske i sit udgangspunkt, så danner de i dag også basis for lægmandshinduisme. Teksterne kan primært kategoriseres som åbenbaringstekster, og bliver blandt de såkaldte tāntrikaer (de som følger tantraernes lære) forstået som vigtigere end de vediske tekster. Inden for den hinduistiske tradition kan de tantriske tekster groft opdeles i tre: śaiva-tantras, vaiṣnava-tantras og śākta-tantras, der har henholdsvis Śiva, Viṣṇu og gudinden som omdrejningspunkt, og som er dem der åbenbarer teksterne for mennesker (Flood 1996, 158-161; Samuel 2008, 1-15; White 2013, 3-40).

Det tantriske ved Kāmākhya-gudinden kommer til udtryk såvel i de tekster, som er tilknyttet hende og hendes sted, som i ritualiseringen omkring Kāmākhya-kulten. Her er ritualernes overordnede formål at bevirke noget og at sætte en transformationsproces i gang. Men idet målet med transformationen for henholdsvis asketerne og for lægfolk tydeligvis er meget forskellige, også selvom de befinder sig inden for samme overordnede, gudindeorienterede, tantriske system, vil jeg i denne artikel operere med to religionsformer: soft core- og hard core-tantrisme.

Mens formålet med den lægmandsbaserede soft core-tantrisme er at transformere Kāmākhyas menstruationsblod fra en uren (ufrugtbar) til en ren (frugtbar) substans med dennesidige formål for øje, er formålet for asketernes hard core-tantrisme derimod at bruge menstruationsblodets urenhed transformativt med en anden verdens perspektiv for øje.

Denne observation understøtter Mary Douglas observation af, hvordan en omgang med det urene skal transformere den energi, som anses at ligge latent i det urene til noget positivt (1984, 159); men den korrigerer den også. Hard coretantrikerne, de såkaldte tāntrikas, ønsker netop at bevare den urene substans som uren. Det er netop det, som er formålet med en venstre-hånds-tantrisme, som er den, der er stærk repræsenteret blandt de sādhu-grupper, heriblandt aghorierne, som valfarter til templet, når Kāmākhya menstruerer. Ved at omgå, indtage og være i berøring med det, som krænker de almindelige renhedsforestillinger, er formålet at overvinde enhver dualisme. Pointen er altså, at de ved at udvise en indifference over for, hvad der konventionelt set anses som rent og urent, vil transcendere dette forhold og dermed enhver dualisme. Det er en proces, som i samme moment kan foregå både i makrokosmos (universet) og i mikrokosmos (den enkelte tāntrika). De må altså tage udgangspunkt i den foreliggende virkelighed, men radikalisere forholdet til den for at frigøre sig fra den eller for at transcendere den. Det betyder, at transformationsprocessen hos dem ikke så meget har fokus på, hvordan substansen (det urene) kan transformeres, men derimod på, hvad den urene substans kan bevirke af transformation hos den, som kommer i berøring med den.

Det, der binder de to tantriske yderpunkter sammen, er altså ikke så meget transformationen af det urene, men snarere, at der sker en transformation, som bevirker noget - den er altså thaumaturgisk. Det passer også til David White 
arbejdsdefinition af tantra, som han fremfører i sin introduktion til sin bog, Tantra in Practice:

Tantra is the Asian body of beliefs and practices which, working from the principle that the universe we experience is nothing other than the concrete manifestation of the divine energy of the godhead that creates and maintains the universe, seeks to ritually appropriate and channel that energy, within the human microcosm, in creative and emancipatory ways (White, 2003, 9).

At gudindens śakti-energi (feminine dynamiske energi) både kan komme til udtryk i verden som en emancipatorisk og som en produktiv skabende energi er de egenskaber, som kan forene asketers og lægfolks bestræbelser.

Formålet med denne artikel er dog ikke kun at vise tantrismens brede spektrum af ontologier og religionspraksis, der alle på en eller anden måde har med omgangen og håndteringen af det urene som omdrejningspunkt, men også at vise, hvordan gudindedyrkelse i sin bredeste form, også kaldet śaktisme, ${ }^{5}$ kan forene disse tilsyneladende modsatrettede religionsformer i en og samme figur. Det er dyrkelsen af Kāmākhya et prototypisk eksempel på. Hendes mangetydige karakter kommer tydeligt til udtryk i ikonografiske og billedlige fremstillinger af hende, og i tekster, såvel de skriftlige som de mundtlige traderede.

\section{Kālikā-purāṇa}

Gudinden Kāmākhya optræder i flere af de tantriske skrifter og forbindes oftest med Durgā, men også med Kālī, der som Mahādevī ('Den store gudinde' manifesterer sig eller 'nedstiger' (avatāra) i forskellige former. Mahādevī er i sig selv en dobbelttydig størrelse, idet benævnelsen både kan referere til det yderste og højeste transcendente omnipotente princip, identificeret med neutrumsordet brahman, og til det feminine skabende element, prakrti (Coburn 1984 \& 1991; Jacobsen 2007a; Kinsley 2008). Kāmākhya, som hun fremstår i templet i Assam, bliver da også kaldt for Mahā-Māyā ('Illusionens gudinde/Gudinden for illusion'), som mens hun danser, skaber et netværk af tilsynekomster for dem, som ikke tilbeder hende, og som holder mennesker fast i genfødslernes kredsløb (Biernacki 2007, 7).

Det er dog i Kālikā-purāṇa, som er en upa-purāṇa, ${ }^{6}$ at Kāmākhya-kulten i Assam har sit primære referencepunkt. Teksten giver ikke kun en mytologisk forklaring på

5 Der er uenighed blandt forskere, hvor bred en vifte af gudindedyrkelse śaktisme dækker over. Visse forskere vil kun tale om śaktisme, hvor gudinden bliver præsenteret som Mahādevī, den øverste omnipotente og transcendente feminine kraft. Andre ser śaktisme som et netværk af alle mulige former for gudindedyrkelse af både tantrisk og ikke tantrisk karakter (se bl.a. Bose 2010, 12-57, McDaniel 2004, og Olesen, ed. 2016 i introduktionen). June McDaniel skelner imellem lægfolks, tantrisk og yogisk śaktisme. Jeg argumenterer også for en bred forståelse af śaktisme (Fibiger 2012), men vil ikke lave den samme form for opdeling, da gudindedyrkelse oftest er sammenvævede i et utal af forskellige, lokale variationer.

6 En upa-purāṇa betyder en mindre purāṇa, hvoraf der siges at være 18, heriblandt Kālikā-purāṇa. Den bedst kendte inden for gudindedyrkelse er nok Devī-Māhātmya- purāṇa, hvor gudinden i form af Durgā dyrkes som universets øverste kraft (Coburn, 1984. 1991; Jacobsen 2007a). 
stedets hellighed, men refererer også direkte til Kāmākhya i hendes forskellige former og deraf følgende mangetydige karakter.

I Kālikā-purāṇa, som i sin nuværende form er fra det 13.-14. årh. og er samlet i Assam, optræder Kāmākhya i mindst to former, der understøtter mindst to typer af religion: De virtuoses alias asketernes og udstigernes religion, som er et brud med den etablerede vedisk forankrede religion; og lægfolkereligion, der indbefatter den etablerede præsteinstitution. I begyndelsen af teksten optræder hun som en øverste guddom, der kan repræsentere den absolutte virkelighed, som de tantriske asketer, forsøger at blive en del af. Hun optræder også som Śivas hustru eller elskerinde her under navnet Satī (Pārvatī), der repræsenterer opretholdelse af dharma i det andet livsstadium som husholder(ske). ${ }^{7}$ Bl.a. hyldes den erotiske og frugtbargivende kærlighed, som findes mellem mand og hustru. Desuden understøtter hun også præsternes rolle i kulten, idet de ritualer, præsterne varetager i Kāmākhya-templet, sikrer, at hun er lægfolk positivt stemt, når de kommer til hende med deres ønsker om dennesidig lykke.

Hendes to sider, som den altomfattende gudinde og som Śivas hustru eller snarere elskerinde, kommer tydeligt til udtryk i de følgende tekststykker fra Kālikā-purāṇa, hvor også stedet, hvor templet er bygget, som helligt, begrundes. I dag er templet et af de fire vigtigste af i alt 51 śākta pịthas, som er helligsteder rundt omkring i det meste af Indien, hvor gudinden eller Śākta menes at have manifesteret sig. Alle 51 steder er fortjenstfulde at besøge som et tīrtha pilgrimssted, men især de fire, hvoraf Kāmākhya-templet er iblandt anses som steder, hvor den kvindelige dynamiske energi er mest fortættet.

Kālikā-purāṇa, som er Śivas lovprisning af Kāmākhya, begynder med følgende indledende strofe:

Now listen especially to the great glory of Kamakhya

Who as the Primordial Force puts the entire world into motion $(1,1)$

Og I kap. 62, vers 1-2 møder vi følgende beskrivelse:

As the Goddess has come to the great mountain Nilakuta to have the sexual enjoyment ${ }^{8}$ with me (Śiva), she is called the (goddess) Kamakhya ("renowed Goddess of desire"), who resides there in secret $(62,1)$ Since she gives love, is a loving female, is embodiment of love, the beloved, she restores the limbs of Kama and also Destroys the limbs of Kama, she is called Kamakhya $(62,2)^{9}$

Især de sidste to linjer i 62, 2 er helt centrale for at forstå de forskellige betydninger, hun og det, at hun er menstruerende, kan tillægges af værdi. Hun både gendanner/skaber og destruerer kama som det seksuelle begær. Og det er især interessant, da det samtidig kobles til Śiva, som er den, hun opsøger og har seksuel-

7 Jeg refererer her til varṇāśramadharma, og den relative dharma som følge de fire livsstadier som henholdsvis bramacārya (ung, student), grhastha (husholder), vanaprastha (skovboer, eremit) og samnyasin (asket)

8 Kan også oversættes: 'to enjoy making love with me'.

9 archive.org/details/KalikaPuranaWithEnglishTranslationIntroductionIndexMissingOPT/page/n19, set 20.11.2018. 
samkvem med. For Śiva selv repræsenterer ikke kun den prototypiske ægtemand han er også asket, hvorved han kombinerer det erotiske og asketiske i en også samme figur. Han er både gift med Pārvāti, som han har børn med, og en asket, idet han også trækker sig tilbage til det vilde i bjergene for at meditere. Ifølge Knut Jacobsen er det netop Śiva, tāntrikaerne forsøger at imitere (Jacobsen, 2007a, 76).

Myten eller snarere myterne om, hvordan stedet er blevet til et śākta pịṭha, og i dag er et af de fire vigtigste pilgrimsteder, ${ }^{10}$ ikke mindst for tāntrikaerne, optræder ifølge Urban i lidt varierende udgaver i flere af de store eper, bl.a. i Mahābhārata, i brāhmanaerne og i purāṇa-litteraturen. Men i dag udgør myten et samlet hele, som overordnet set, og i en lidt forkortet gengivelse lyder, som følger. Jeg trækker her på bl.a. Urban (2009) og Biernacki (2007):

Śiva bliver gift med gudinden Satī, som er datter til kongen Dakṣa. Dakșa kan desværre ikke særligt godt lide sin svigersøn, da han altid optræder i sin destruktive og frygtlige form, når de er sammen. Så da Dakșa arrangerer et stort yajña (vedisk offentligt ildoffer, et såkaldt śrauta-ritual), inviterer han ikke Śiva med. Det bliver Satī så oprørt over, at hun begår selvmord ved at kaste sig på offer-ilden. Hun viser således sin fulde loyalitet over for sin mand ved sin selvopofrelse. ${ }^{11}$

Da Śiva hører, hvad der er sket, bliver han så vred, at han viser sig i sin frygteligste form som Mahārudra, og han begynder ikke kun sin voldsomme destruktive dans, der skaber en massakre blandt de indbudte gæster, han dræber tilmed sin svigerfar ved at kappe hovedet af ham. Og for at ydmyge og vanære Dakṣa giver Śiva ham i stedet et hoved fra en af de geder, som ellers skulle være blevet ofret under Dakșas yajña. Således bliver Dakșa sit eget offer, hvilket ikke kun skal ses som et klart opgør mod den vediske royalt støttede offerkult, men også som en begrundelse for, hvorfor Kāmākhya skal have blodige ofringer -- ikke mindst i form af geder.

Tidligere og frem til 1832, hvor englænderne forbød det, fik hun ifølge flere kilder menneskelige ofringer. I den forbindelse bliver hun også kaldet Kāmākṣị ('den med de onde øjne') - forstået som den, der kan lade det onde øje hvile på den, som ikke tækker hende og tilbeder hende med de ofringer, hun behøver. ${ }^{12}$

Efter at have slået sin svigerfar ihjel tager Śiva sin døde hustru på sine skuldre; men det bestyrker kun hans destruktive vrede, der nu er så stærk, at de andre guder er bekymrede for, at det i sidste ende kan betyde hele universets undergang. For at afbøde, at det skal ske, og for at pacificere og egentlig også transformere de stærke destruktive kræfter, som Śiva besidder, til konstruktive kræfter, trænger guderne ind i Satī's krop og splitter liget ad indefra. De forskellige ligdele lander forskellige steder i Indien/Pakistan, og de danner i dag basis for tilbedelse, her i form af sākta-pīthas. I veneration over for sin hustru vælger Śiva at manifestere sig de steder i form af en lingam ('tegn', fallos, men også en anikonisk repræsentation), hvilket ikke kun viser

10 Udover Kāmākhya-templet i Assam er det Jagannath-templet i Puri i og Berhampur templet begge i Odisha og Kālì-ghat templet i Kolkata i Vest-Bengalen.

11 Nogle forskere peger på denne mytologiske historie, som baggrund for eller legitimering af enkebrænding, der netop kaldes Satī. Her kaster enken sig på sin afdøde mands ligbrændingsbål, og brænder op sammen med mandens lig. (Se fx Ramos 2017).

12 The Concise Oxford Dictionary of World Religions 1997. 
Śiva i sin tæmmede og frugtbargivende form, men også at han underkaster sig gudinden efter sit destruktive vredesudbrud. Han bliver nu den, som tilbeder hende og ikke vice versa, hvilket også markeres ved, at det er Śiva, som lovpriser gudinden i Kālikā-purāṇaen. Netop dette aspekt bliver også tydeliggjort i billedelige fremstillinger af Kāmākhya, som danser ovenpå Śiva.

Blandt de mest vitale dele af Satīs ligrester er hendes yoni (kvindelige kønsorganer, skede), som lander, der hvor Kāmākhya-templet er bygget i Assam. Yonien koblet til Śivas lingam understreger ikke kun stedets skabende kvaliteter, ${ }^{13}$ men danner også basis for en diskussion om, hvordan yonien og det seksuelle skal tolkes i forhold til en asketisk livsførelse, som igen kan begrunde tantrikāernes interesse for stedet.

Aktor refererer i sin note 1 i sin artikel "'Respect Pollution' - urenhed og renselse i hinduismens rituelle personhierarki" i dette nummer af Religionsvidenskabeligt Tidsskrift netop til denne diskussion. Omdrejningspunktet er, hvordan især det fjerde af de i alt fem forbudte stoffer, også kaldet de fem M'er: madya, matsya, māṃsa, mudrā og maithuna, som venstrehånds-tantrikere indtager eller er $\mathrm{i}$ berøring med under deres ritualer.

Mens man stort set er enige om, at madya refererer til alkohol, māmsa til kød, maithuna til samleje og matsya til fisk, er man ikke enige om betydningen af mudrāa, der bliver tolket som værende lige fra kogt og tørret korn til et elskovsmiddel eller til et segl. White $(2003,83-84)$ er fortaler for at forstå mudrā som et segl, der ifølge ham optræder i mange tantriske tekster som et kodeord for den kvindelige ritualpartners kønsorgan. ${ }^{14}$ Kāmākhya-templets tiltrækningskraft for venstrehånds-tantrikerne understøtter Whites oversættelse. Yonien kan desuden indskrives i et mikro-makrokosmisk korrespondance system og som den basale cakra i en esoterisk tantrisk anatomi, (som bl.a. ses i Hațha yoga pradīpikāen). Her udgør yonien den basale cakra, der åbner op for den centrale akse, sushumna-nādì, og er stedet, hvor kundalini-śakti har sit udgangspunkt. Netop denne yogaform er udbredt blandt venstrehåndstantrikere såsom nāth-yogier, kāpālikaer og aghorier.

Som Urban (2009) påpeger, er myten en interessant omvendt udgave af den kosmogoniske Purușa-hymne (Rg veda 10,90). For mens guderne deler Purușa i Purușa-hymnen og dermed skaber såvel universets orden og den sociale orden, har Satī-historien nærmest apokalyptisk og potentielt destruktiv karakter. Ved de andre guders indgriben og ved at lade hendes kreative kræfter spredes på jorden dæmmes der dog op for det potentielt destruktive, og der skabes rum for det kreative. Selvom det er Śiva, der er den primære aktør i selve destruktionsakten, og selvom det er de andre guder, som afbøder, at universet går under, er det gudinden, som både er baggrunden for, at det destruktive sættes i gang, og det er fordelingen af hendes

13 Af andre vitale dele med hver deres symbolik, som lander rundt omkring i Indien/Pakistan er hendes hoved, hendes fødder, hendes bryster, hendes navle, hendes lår, hendes hals. De er alle i dag vigtige pilgrimssteder for især gudindetilbedere og tāntrikaer.

14 I flere tekster beskrives det, hvordan den mandlige tantriker skal have seksuel samkvem med en lavkastekvinde, men uden at få udløsning. Sædens kraft skal jo netop ikke skabe liv i denne verden, men den skal internaliseres, så den kan fungere som en stærk transformativ energi i tantrikeren selv (se fx Mallinson 2018). 
kropsdele, og det at Śiva bliver til en lingam, der gør, at det destruktive tæmmes og i stedet bliver konstruktivt. Derfor er hele Kālikā-purāṇaen også en kærlighedserklæring fra Śivas side til Satī her i form af Kāmākhya.

\section{Billedlige fremstillinger af Kāmākhya}

Kāmākhya afbildes ofte som en meget smuk ung kvinde med tolv arme og seks hoveder af varierende farver. Hun er klædt i en rød sari, har overdådige smykker på og er ofte omkranset af blomster, blandt andet hibiscus. Hun holder i hver af de ti hænder henholdsvis en lotus, en trefork, et sværd, en klokke, en diskos, en bue, pile, et scepter, en hyrdestok til at styre okser med og et skjold. De sidste to hænder holder hun foran sig, hvoraf den ene enten holder om en skål af guld eller om et menneskekranie. I visse sammenhænge afbildes hun alene; i andre sidder hun på en lotus, som kommer fra navlen af guden Śiva, som igen ligger oven på en løve, der er Kāmākhyas ridedyr. ${ }^{15}$ Hun kan desuden være flankeret af skaberguden Brahma og Vișṇu, opretholderen af dharma, som hver især også sidder på en lotus (billede 1). Det er også disse to guder, som reagerer i myten i forbindelse med Śivas destruktive dans og afbøder universets undergang ved at trænge ind i gudindens døde krop og skiller den ad. I andre sammenhænge afbildes hun som en nøgen menstruerende kvinde (billede 2), eller også repræsenteres hun blot af en menstruerende vagina, som er centrum for pūjā (billede 3).
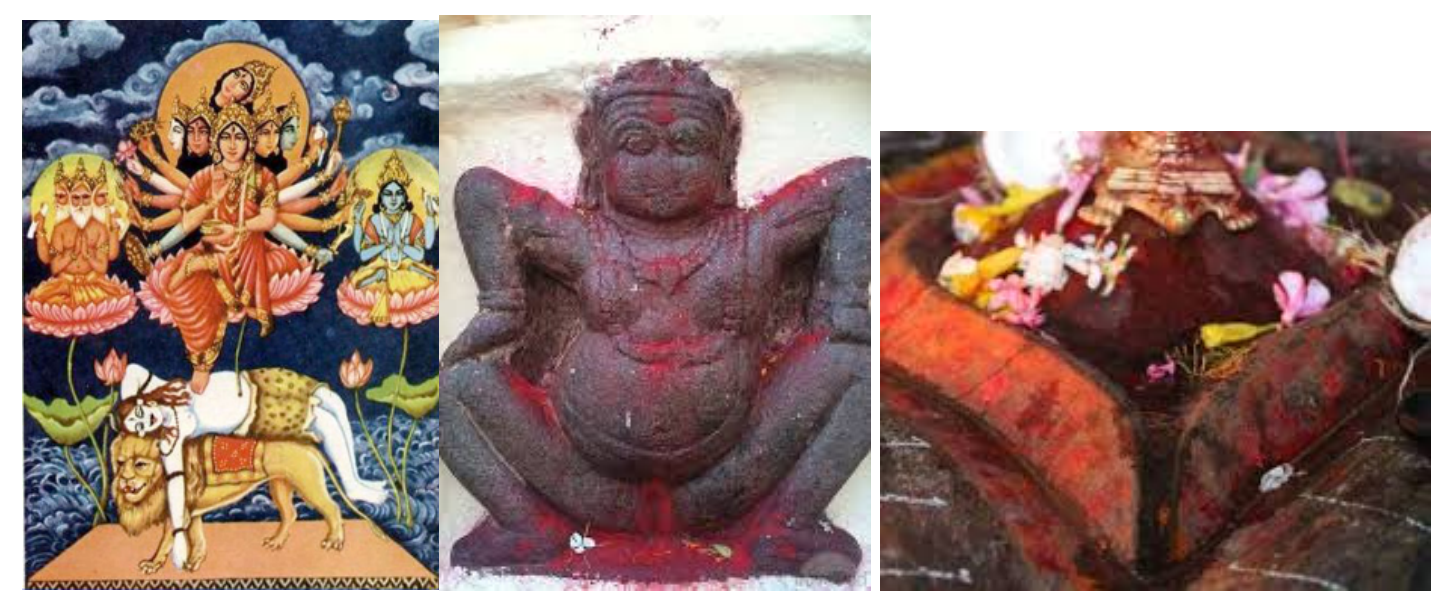

Afbildninger af Kāmākhya

Ved en hurtig analyse af hendes forskellige fremtrædelsesformer. inklusiv de attributter, hun holder i hænderne, fremgår det, at hun er en meget kompleks gudinde. Hun viser med sit scepter, at hun er herskerinde (royale træk) og nok den øverste hersker, idet hun sidder i centrum omgivet af trimūrti (Brahma, Viṣnu og

15 Løven eller tigeren er gudinde Durgās ridedyr, hvilket markerer at Kāmākhya anses som en af Durgās avatāras ('nedstigninger') eller manifestationer. 
Śiva), ${ }^{16}$ som alle er mandlige guder. Dog markeres der en helt særlig tæt relation imellem Kāmākhya og Śiva, idet hun er placeret i den lotusblomst, som vokser ud af Śivas navle. Vigtigt er det dog at fremhæve, at hun danser på og dermed også undertvinger ham. Netop dansen, og det at hun danser alene, ligesom Śiva også gør det (som Națarāja) i andre myter med ham som centrum, er også noget, som fremhæves i Kāmākhya-kulten - primært i de mundtlig overleverede historier om hende. Her fremstilles Kāmākhyas dans som noget, hun gør for sin egen skyld. Hun danser nemlig kun, når templets døre er lukkede og uden at nogen - på nær måske præsten - må kigge på. Og netop det med ikke at tiltuske sig et darśana (syn, skue) er omdrejningspunktet for en mundtlig traderet myte om hende, og som alle der dyrker hende kender.

Myten beskriver kort, hvordan en præst (pūjāri, pandit) ved navn Kendukalai, som pga. hans store veneration for hende er den eneste, der får lov til at kigge på, når Kāmākhya danser om natten inde i templet. Desværre fortæller præsten om hendes spektakulære natlige dans til en konge ved navn Naranarayan, hvis begær straks vækkes. Kongen presser derfor Kendukalai til, at han får et natligt darśana af hende. Kendukalai placerer derfor kongen et sted, hvor der er en lille revne i templets mur, så han kan kigge ind. Det opdager Kāmākhya selvfølgelig, og hun slår ikke kun den forræderiske præst ihjel, hun nedkalder også en evig forbandelse over for kongen og hans efterfølgere om, at det vil få uforudsete destruktive konsekvenser for riget, hvis de på nogen måde igen vil forsøge at få et darśana af hende (Biernacki 2007, 3-4). Op til i dag er denne episode ikke kun en forklaring på, at kongens efterfølgere må holde afstand til templet, men er også et opgør mod den verdslige magt. Desuden understreger historien også betydningen af, at kultpersonalet overholder praksis også selvom de kan være fristet til andet. Hvem vil ikke gerne se Kāmākhyas erotiske dans om natten?

Kāmākhya er tydeligvis også kriger og kan bekæmpe dæmoniske kræfter med sin trefork, sin diskos, sit sværd, sin bue og sine pile og beskytte sig med sit skjold. Og så kan hun med sin kvæg-stok genne kvæg sammen, hvilket sammen med klokken ${ }^{17}$ udgør et frugtbarhedssymbol. Samtidig med det hylder hun også det tantriske asketideal ved at have en tiggeskål eller et menneske-kranie i hånden, som hun kan bruge som sin drikkeskål.

I denne billedlige fremstilling, som umiddelbart beskuet tegner en paradoksal figur, er pointen netop, at hun i sin paradoksalitet kan forene to modsatrettede idealer i den hinduistiske tradition: det aksiale udstiger- og asketideal (hard core-tantrisme) med det arkaiske frugtbarhedsideal (soft core-tantrisme).

16 Trimūrti ('tre former') er et forsøg på at systematisere det store hinduistiske gudepantheon ved at hævde. at alle andre guder er udsprunget af disse tre, der samlet skaber, opretholder og destruerer verden i en cyklisk proces. De er dermed med til at opretholde verdens gang.

17 Klokken kendes fra den hinduistiske tempelgudstjeneste pūjāen, men kan også bruges under asketers meditation. Derfor har den meget bred symbolik. 


\section{Kāmākhya, som gudinden der kan forene modsætninger}

Som de ovenstående myte- og billedanalyser forhåbentlig viser, er Kāmākhya henholdsvis som den omnipotente Mahādevi og som Śivas hustru og elskerinde en sammensat figur, der forener tilsyneladende modsætninger: det verdensaffirmative og det verdensfornægtende. Hun er med andre ord både 'a Goddess of Tooth' og 'a Goddess of Breast', hvilket er en skelnen som O'Flaherty (1980, 90-91), der er inspireret af Ramakrishna, har formuleret i forsøget på at indfange det brede spektrum af gudinderepræsentationer, som vi finder inden for hinduismen. Og mens 'Brystets gudinde' inkarnerer moderlighed og det verdensaffirmative, inkarnerer 'Tandens gudinde' det modsatte. Hun er uafhængig, og hun kan være både erotisk og farlig. Men her er det en pointe, at hun jo netop er destruktiv i en større sags tjeneste. Hun slår bl.a. ihjel for at opretholde universet eller for at fjerne dæmoniske og destruktive kræfter.

Mandakranta Bose (2010, 12-13) indskriver gudinden i en overordnet matrix, der både bevæger sig på et filosofisk (her vil jeg tilføje soteriologisk), og på et socialt (her vil jeg tilføje dennesidigt orienteret) niveau. Disse to niveauer tager begge udgangspunkt i fire, hvad Bose kalder, arketyper: (1) mor/og plejer af afkom; (2) den der styrker verdslig magt/beskytter; (3) hustru/hjælper/datter; (4) ødelægger. En pointe er, at de ikke skal forstås som adskilte arketyper, men at de samlet dækker over, hvad en gudinde kan tillægges af kendetegn.

Her er det vigtigt at slå fast, at en Mahādevī ved netop at være en Mahā ("stor) gudinde omfatter alle aspekter i en og samme figur. Det er også derfor, at en menstruerende gudinde som Kāmākhya kan appellere til såvel asketer (hard coretantrikere) og lægfolk (soft core-tantrikere) også selvom de har nærmest modsatte mål for øje. Henholdsvis det verdensaffirmative og det verdensfornægtende, og hvor menstruationsblodet tillægges nærmest modsat rettet symbolik.

For mens lægfolk og for den sags skyld også kultpersonalet kobler deres tantrisme til den vediske mainstream hinduisme, der har arkaiske træk, har tāntrikaerne netop ved at være udstigere også valgt at vende det etablere og dermed også den hinduistiske mainstream tradition ryggen, hvilket også de to gengivne myter begrunder. Det kommer også bogstaveligt til udtryk, ved at det bestemte indvielsesritual, de udfører, hvorefter de anses som 'socialt døde'; dvs. døde for samfundet.

Det, der forbinder de to grupper, er deres fokus på blodets transformative og thaumaturgiske egenskaber. Men mens formålet for tāntrikaerne er at transformere kroppen i forhold til et mikro-makro-kosmisk korrespondance system og i sidste ende opnå en spirituel realisering (sädhana) eller ren bevidsthed (Flood 2006, 168), er fokus for lægmænd og kult-personalet at transformere eller at sikre mikrokosmos, som i en arkaisk analogisme bør afspejle det velordnede makrokosmos. Gudinden kan ved at bevæge sig både på et filosofisk og et socialt niveau indbefatter begge mål.

En tredje dimension, som kan være interessant at nævne i denne sammenhæng, er forholdet imellem tāntrikaerne og lægfolk ved Kāmākhyatemplet. Idet tāntrikaerne ved hjælp af gudinden kan transcendere sig selv, transcenderer de også deres 
afhængighedsforhold til naturen, som de nu kan manipulere med. De opnår siddhi, dvs. magiske evner, som får lægfolk til ikke kun at opsøge gudinden, men også tāntrikaerne. Det skaber en konkurrencesituation imellem den etablerede og institutionaliserede Kāmākhya-kult, der også knytter sig til den vediske mainstreamhinduisme, og til hard core-tantrismen som et klart korrektiv. Det er også, hvad historien om præsten Kendukalai og kongen Naranarayan refererer til.

\begin{abstract}
Afslutning
I sin bog, A Comparative Sociology of World Religions, fra 2001 fremhæver Stephen Sharot det transformative og thaumaturgiske som to overordnede forskellige mål for religionsudøvelse. Første gang Sharot præsenterer læseren for sin forståelse af det transformative og det thaumaturgiske er på s. 4, hvor han tager udgangspunkt i Max Webers skelnen imellem soteriologiske mål og dennesidige mål for religionsudøvelse. Det transformative knytter Sharot til den soteriologiske religionsudøvelse, der har fokus på ønsket om en radikal forandring i naturen, samfundet og i individet. Det thaumaturgiske derimod forbinder Sharot med den religionsudøvelse, som er dennesidigt orienteret, og som har et primært ønske om at blive en befriet for syg- og dårligdomme. Senere i bogen i Sharots afsnit om religion i Indien fremhæver han interessant nok det særlige forhold, som findes imellem asketer og lægfolk, hvor de indiske asketer netop tillægges thaumaturgiske evner, hvorfor de opsøges af lægfolk.

Jeg har i nærværende artikel og med fokus på Kāmākhya-kulten specifikt og tantrisme mere generelt fremhævet, at det transformative og det thaumaturgiske er centrale elementer både i en tantrisme soft, der bedst kan betegnes som en arkaisk religionsform med dennesidige mål for øje og i tantrisme hard i form af tāntrikaer, der klart repræsenterer en aksial udstiger-religion og med et soteriologisk mål for øje. Begge grupper forholder sig begge til gudindens menstruationsblods thaumaturgiske muligheder, og hvor det er blodet og ikke mindst omgangen med det urene fluidum, som sætter en ønsket transformativ proces i gang: hos tāntrikaerne som en indre proces med et verdensafvisende fokus, hos lægfolk som en ydre proces med verdensaffirmative mål. ${ }^{18}$

Som det ses i myterne, betyder den korrekte omgang med Kāmākhya i den rette atmosfære alt, for at Kāmākhyas śakti-energi har en konstruktiv effekt, hvilket læses forskelligt hos henholdsvis lægfolk og asketer. Desværre er den rette atmosfære
\end{abstract}

18 Som en hjemmeside understreger, kan en pūjā ved Kāmākhya-templet i Assam "fills life with bliss, joy and enthusiasm, it can remove the tension from life whether it is love life or marriage or business or career or jobs. It removes all the negativity and creates a positive environment.

It helps to erase the differences and builds a bridge of trust between couples or partners. Special pujas are conducted to attracts wealth and riches, protect them from all enemies, creates a balance among partners and families; resolves marital problems, increases romance and passion, protects from black magic, protects from spirits and creates positivity around family."

(https://www.youngisthan.in/faith/kamakhya-devi-goddess-of-desires/65318, set d. 3.12.18)

Den menstruerende gudinde 145 
omkring templet truet - ikke så meget af de mange pilgrimme, som kommer for at få et darśana af Kāmākhya, som af turister, der primært ønsker at få et darśana af pilgrimmene. Turistindustrien udgør med hoteller, kunstigt lys, larm og ikke velset adfærd omkring templet en uforudset forureningskilde, som der ikke er taget højde for i myterne eller i ritualerne. Mange af pilgrimmene er bekymrede for, at Kāmākhya reagerer med at danse sin destruktive dans.

\section{LITTERATUR}

Bellah, Robert N.

2011 Religion in Human Evolution. From the paleolithic to the axial age, Harvard University Press. https://doi.org/10.4159/harvard.9780674063099

Biernacki, Loriliai

2007 Renowed Goddesses of Desire. Women, Sex and Speech in Tantra, Oxford University Press.

Bose, Mandakranta

2010 Women in the Hindu Tradition. Rules, roles and exceptions, Routledge. https://doi.org/10.4324/9780203864197

Coburn, Thomas B.

1984 Devī Māhātmya: The Crystallization of The Goddess Traditioni, Delhi: Motilal Banarsidass Publishers.

1991 Encountering the goddess: a translation of the Devī-māhätmya and a study of its interpretation, Albany, State University of New York.

Concise Oxford Dictionary of World Religions, The

1997 Se: https://www.encyclopedia.com/religion/dictionaries-thesauruses-pictures-and-pressreleases/kamakhya; tidligere publiseret af Oxford University Press.

Descola, Philippe

2013 Beyond Nature and Culture, Chicago University Press.

Douglas, Mary

1984 Purity and Danger: An Analysis of the Concepts of Pollution and Taboo, Ark Paperbacks [1. ed. 1966].

Fibiger, Marianne Qvortrup

2004 "Den hinduistiske institutionalisering af den kvindelige sakti-energi”, in: Jens Peter Schjødt, , Armin W. Geertz \& Hans J. Lundager Jensen, eds., Det brede og det skarpe: Religionsvidenskabelige Studier, Anis, 95-108.

2012 "When the Hindu-Goddess Moves to Denmark: The Establishment of a Sakta-Tradition", Bulletin for the Study of Religion, 41 (3), 29-36. https://doi.org/10.1558/bsor.v41i3.29

Flood, Gavin

1996 An Introduction to Hinduism, Cambridge University Press.

2006 The Tantric Body. The Secret Tradition of Hindu Religion, I. B. Tauris.

Jacobsen, Knutt A.

2007a Hyllest til Gudinnen. Visjon og tilbedelse av hinduismens store gudinne, Emilia forlag.

2007b "Indias religioner - Jainismen, buddhismen, hinduismen, sikhismen”, in: Ingvild Sælid Gilhus \& Lisbeth Mikaelson, eds., Verdens levende religioner, Pax Forlag, 24-135.

Kinsley, David

2008 Tantric Visions of the Divine Feminine. The Ten Mahāvidyās, Delhi: Motilal Banarsidass [1. ed. 1998].

Mallinson, James

2018 "Yoga and Sex: What is the purpose of Vajrolimudra?", in: Karl Baier, Karl, Phillipp A Maas, Karin Preisendanz, eds., Yoga in Transformation, Vienna University Press. 
McDaniel, June

2004 Offering Flowers Feeding Skulls. Popular Goddess Worship in West Bengal, Oxford University Press. https://doi.org/10.1093/acprof:oso/9780195167900.001.0001

O'Flaherty, Wendy Doniger

1980 Women, Androgynes and Other Mythical Beasts, University of Chicago Press.

Olesen, Bjarne W., ed.

2016 Goddess Traditions in Tantric Hinduism. History, practice and doctrine, Routledge.

Ramos, Inna

2017 Pilgrimage and Politics in Colonial Bengal. The Myth of the Goddess Sati, Routledge. https://doi.org/10.4324/9781315223148

Sharot, Stephen

2001 A Comparative Sociology of World Religions. Virtuosos, priests and Popular Religion, New York University Press.

Urban, Hugh

2009 The Power of Tantra: Religion, Sexuality and the Politics of South Asian Studies, I. B. Tauris.

2012 Tantra, Sex, Secrecy, Politics, and Power in the Study of Religion, Delhi: Motilal Banarsidass Publishers, Delhi.

White, David Gordon

2003 The Kiss of the Yogini: 'Tantric Sex' in Its South Asian Contexts, The University of Chicago Press. https://doi.org/10.7208/chicago/9780226027838.001.0001

White, David Gordon, ed.,

2013 Tantra in Practice, Delhi: Motilal Banarsidass Publishers.

Websider:

https://archive.org/details/KalikaPuranaWithEnglishTranslationIntroductionIndexMissingOPT/page/n 19 (set 20.11.2018).

https://www.reckontalk.com/secrets-of-kamakhya-devi-temple-menstruating-goddess-in-india/ (set 3.12.2018).

https://www.youngisthan.in/faith/kamakhya-devi-goddess-of-desires/65318 (set 3.12.2018).

Marianne C. Qvortrup Fibiger, lektor, ph.d. Afdeling for Religionsvidenskab, Aarhus Universitet 